\title{
Experimental Tests of Static Friction Coefficient for Selected Material Combinations of Expanded Graphite - Steel Used in Sealing Nodes
}

\author{
Aleksandra REWOLIŃSKA, Karolina PERZ, Grzegorz KINAL \\ Poznan University of Technology Instytute of Machines and Motor Vehicles, Poznan, Poland, \\ E-mail: aleksandra.rewolinska@put.poznan.pl
}

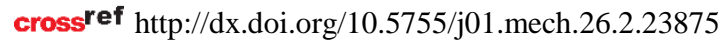

\section{Introduction}

The material combination expanded graphite steel is widely used in sealing technology, both in dynamic and static joints $[1,2]$. This popularity results from the properties of expanded graphite, such as extremely low density, specific surface and high thermal resistance [37]. Not without significance are the tribological properties of graphite, which in the case of movement joints determine the proper functioning of the combination. Tests [8] of selected tribological properties of the mentioned combination showed that there is a noticeable difference between the coefficient of static and kinetic friction, which can significantly affect the operation of machines and equipment, especially those working in the system of motion and rest. This influence may be unfavorable, e.g. when it is the cause of vibrations resulting in disturbances in the movement of rubbing elements, the so-called stickslip phenomenon, which is characteristic for graphite [9, 10]. Launch of a machine can also be difficult, especially if the contact time between the cooperating surfaces is longer. Then the processes of atoms diffusion at elementary contact surfaces intensify, which results in an increase in the strength of adhesion joints with time [11]. The source literature $[12,13]$ presents numerous studies on the said tribological phenomenon occurring in the polymer-steel combination. Graphite in these studies is often an additive to the polymer, which is introduced in various forms and quantities [14 - 16]. In general, published research results [17 - 19] indicate that graphite, as an additive, improves resistance to wear of the cooperating material, lowers the temperature of friction vapor, stabilizes the friction coefficient and reduces noise. The amount of graphite introduced as an additive is important - too much graphite can worsen the friction conditions for a given combination. In practice, there is also a combination of expanded graphite - pure or with additives - cooperating with a steel element. There is little research into such combinations. The author [20] has shown in her research that the coefficient of friction decreases with the increase in the density of graphite material. The situation is the opposite when the numbers of combination work cycles increases. At that time, an increase in the friction coefficient was noted. These studies concern kinetic friction, whereas problems occur when launching the graphite-steel combination, i.e. for static friction, which is what the manufacturers and users of seals say about. Therefore, it is necessary to recognize the phenomenon of static friction occurring in the abovementioned combinations. Knowledge of this issue will enable better design and selection of seals for given applications in the future, which will allow, among other things, to eliminate start-up problems. It is important because the tested seals often work in the motion-rest system.

The aim of this work is to determine the value of static friction coefficient for selected graphite materials cooperating with a steel mandrel for various load values and number of work cycles.

\section{Test object}

Four commercial graphite materials were selected for tests and characterized in Table 1. These are graphite rings with dimensions $40 \times 25 \times 10 \mathrm{~mm}$.

Table 1

Characteristics of graphite materials selected for testing

\begin{tabular}{|l|l|c|}
\hline Graphite name & \multicolumn{1}{|c|}{ Description } & Density, $\mathrm{g} / \mathrm{cm}^{3}$ \\
\hline Grafmet 950 & $\begin{array}{l}\text { Pressed ring made of } \\
\text { pure expanded graphite } \\
\text { of industrial purity. }\end{array}$ & 1,8 \\
\hline Grafmet 950 TF & $\begin{array}{l}\text { Pressed ring made of } \\
\text { pure expanded graphite } \\
\text { of industrial purity with } \\
\text { PTFE additive. }\end{array}$ & 1,4 \\
\hline Grafmet 950 TF & as above & 1,8 \\
\hline Grafmet 950 I & $\begin{array}{l}\text { Expanded graphite } \\
\text { rings laminated with } \\
\text { austenitic steel foil. }\end{array}$ & 2,4 \\
\hline
\end{tabular}

The counter-sample is made of stainless steel with a hardness of $40 \mathrm{HRC}$ in the form of a mandrel with a diameter of $25 \mathrm{~mm}$ and a roughness of $R a=0.98 \div 1.12 \mu \mathrm{m}$. The device on which the tests were carried out allows to conduct sliding friction tests in a reciprocating motion (Fig. 1).

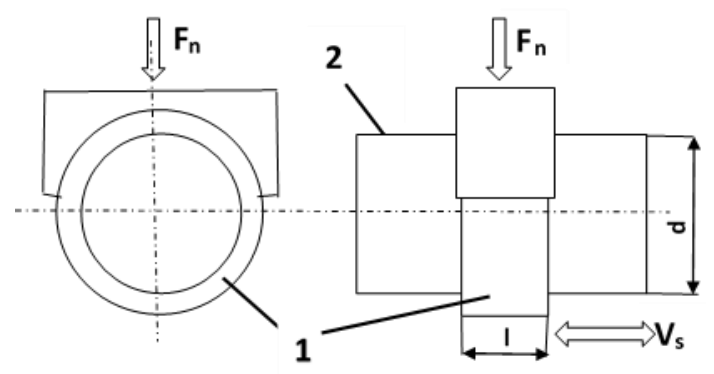

Fig. 1 Test stand used to determine the static friction force in reciprocating motion; 1 - sample (graphite ring), 2 - counter-sample (steel mandrel), $F_{n}$ - contact force, $V_{s}-$ mean velocity 
During the test, the sample in the form of a ring, attached to the holder, was pressed against the steel sample with $F_{n}$ force. The system that moved the counter-sample consisted of two trolleys lying on top of each other, with bearings so that they could move in the same direction. The slip force $F_{t}(t)$ was recorded at a frequency of $100 \mathrm{~Hz}$ with a strain gauge sensor. To determine the static friction values $F_{s t}$, the following procedure was used:

- selecting the "peak" of static friction force (Fig. 2);

- calculation of the average value from selected peaks (for example, for 500 cycles we obtain 1000 values of static friction force - 500 peaks in one direction and 500 peaks during friction in the other direction);

- determination of the static friction coefficient $\mu_{s t}$.

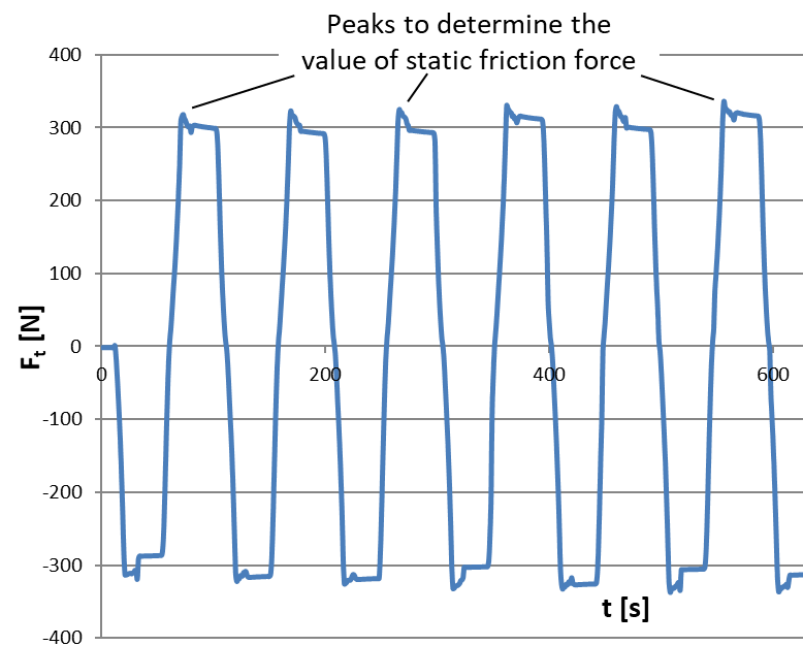

Fig. 2 An exemplary diagram of the friction force $F_{t}$ recorded during the experiment. Peaks at the beginning of cycle are the values of a static friction force

During the tests, the graphite sample was pressed by $F_{n}$ force onto a metal counter-sample by a pneumatic pressure actuator. The average pressure value $p$ was determined as:

$$
p=\frac{F_{n}}{d l}
$$

where: $F_{n}$ is normal force; $d$ is counter-sample diameter; $l$ is sample width.

\section{Movement tests of the combination}

\subsection{Test conditions}

The test conditions are shown in Table 2. Before starting the appropriate measurements, the test pair of materials was broken in until the expanded graphite sample touched the entire surface to the steel counter-sample. The experiment was repeated 3 times for each set of materials. New graphite samples were prepared each time. The steel counter sample was cleaned with ecetone each time. After each of the three series of tests, the samples were weighed. The measurements were made with an accuracy of $0.01 \mathrm{~g}$. The results are summarized below.

\section{Results and discussion}

\subsection{Unite pressure}

As a result of tribological cooperation between the steel mandrel and selected graphite rings, it was noted that the static friction coefficient decreases with increasing pressure (Figs. $3-6$ ).

For selected materials, the friction coefficient at pressures equal to $5 \mathrm{MPa}$ slightly increases. The highest instability of measurements occurs at pressures of $0.5 \mathrm{MPa}$, especially for Grafmet 950 material. The exception is Grafmet $950 \mathrm{TF} 1.8$, which is characterized by high stability (standard deviation - 0.001). Moreover, this material showed the lowest value of the static friction coefficient for the tested pressures.

Table 2

Test conditions for the test of expanded graphite - steel

\begin{tabular}{|c|c|c|c|}
\hline Stage & $\begin{array}{c}\text { Unite pressure } \\
p, \mathrm{MPa} \\
\end{array}$ & $\begin{array}{l}\text { Number } \\
\text { of cycles }\end{array}$ & $\begin{array}{c}\text { Mean speed } \\
V_{s}, \mathrm{~mm} / \mathrm{s}\end{array}$ \\
\hline Breaking-in & 1 & 100 & \multirow{13}{*}{20} \\
\hline \multirow{4}{*}{1} & \multirow{4}{*}{0.5} & 1 & \\
\hline & & 500 & \\
\hline & & 1500 & \\
\hline & & 3000 & \\
\hline \multirow{4}{*}{2} & \multirow{4}{*}{2.0} & 1 & \\
\hline & & 500 & \\
\hline & & 1500 & \\
\hline & & 3000 & \\
\hline \multirow{4}{*}{3} & \multirow{4}{*}{5.0} & 1 & \\
\hline & & 500 & \\
\hline & & 1500 & \\
\hline & & 3000 & \\
\hline
\end{tabular}

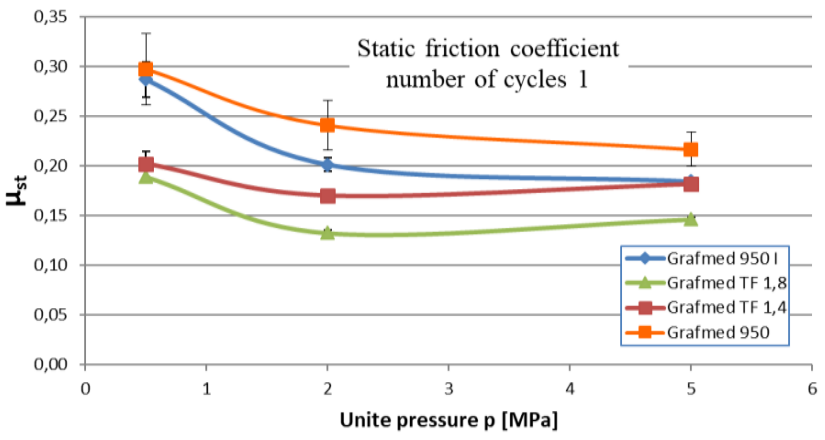

Fig. 3 Static friction coefficient dependence on unite pressure for selected material sets (No. of cycles 1)

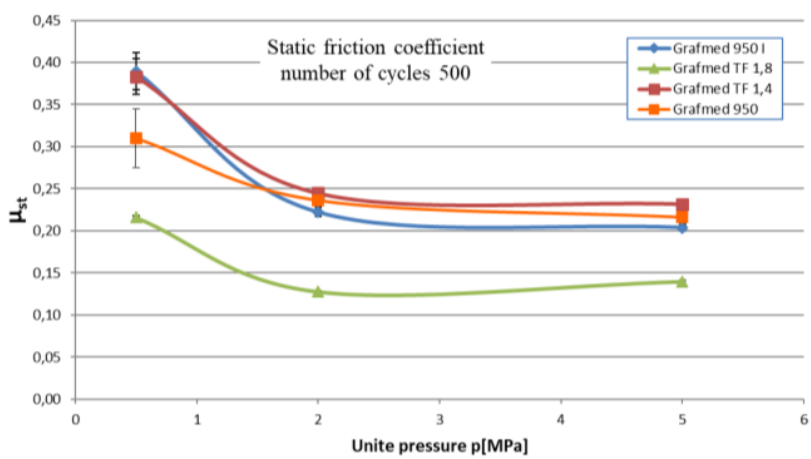

Fig. 4 Static friction coefficient dependence on unite pressure for selected material sets (No. of cycles 500) 


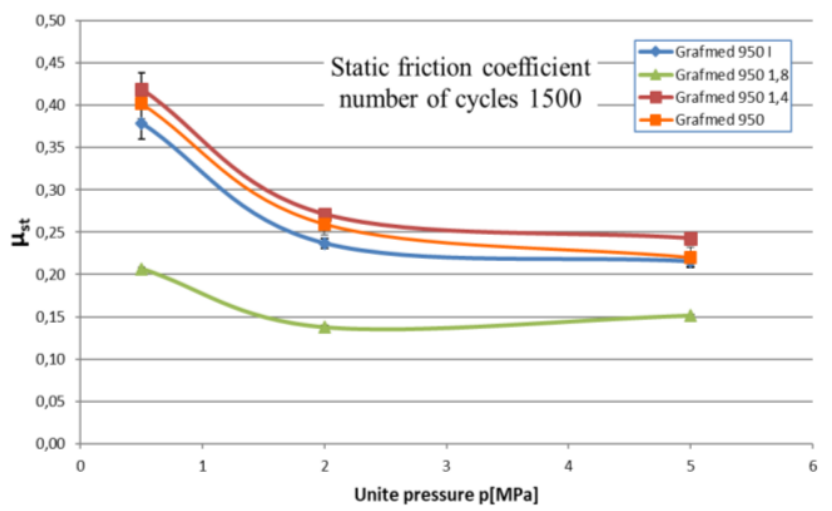

Fig. 5 Static friction coefficient dependence on unite pressure for selected material sets (No. of cycles 1500)

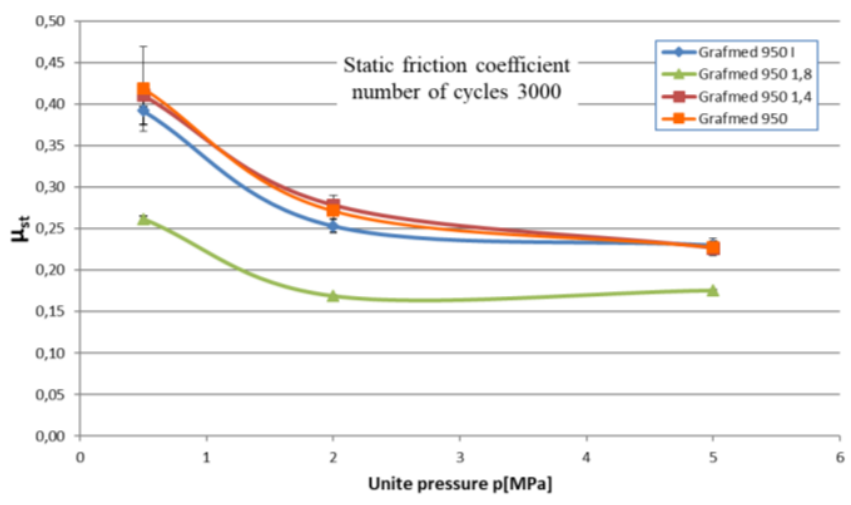

Fig. 6 Static friction coefficient dependence on unite pressure for selected material sets (No. of cycles 3000)

\subsection{Work cycles}

Friction coefficient tests were performed for the following number of work cycles: 1, 500, 1500 and 3000. The lowest friction coefficient was found for Grafmet 950 FT material with a density of $1.8 \mathrm{~cm} 3 / \mathrm{g}$ (Figs. $7-9$ ).

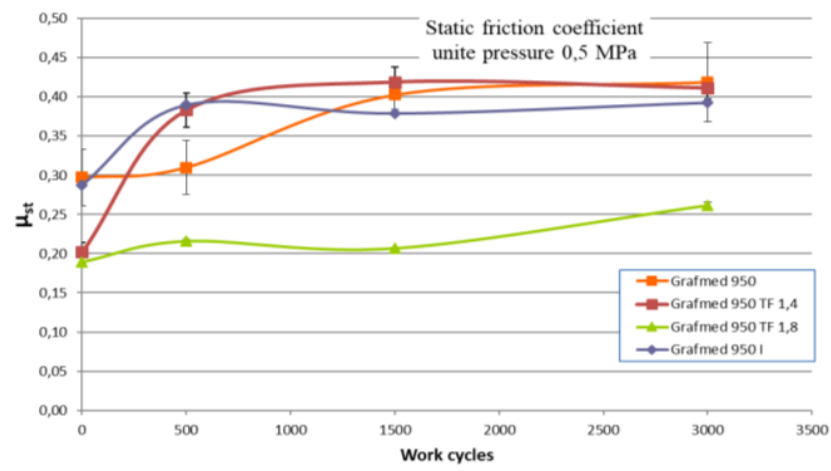

Fig. 7 Static friction coefficient dependence on the number of work cycles for selected material sets for $0.5 \mathrm{MPa}$ pressure

With the increase in the number of work cycles, the coefficient for the above material increased, e.g. from 0.13 to 0.17 at $2 \mathrm{MPa}$ pressures. In general, with the increase in the number of work cycles, the coefficient increases. For example, for Grafmet $950 \mathrm{TF} 1.4$ material from 0.2 to 0.4 at $0.5 \mathrm{MPa}$ pressures. Pure expanded graphite at the lowest pressures of $0.5 \mathrm{MPa}$ showed a lack of stability.

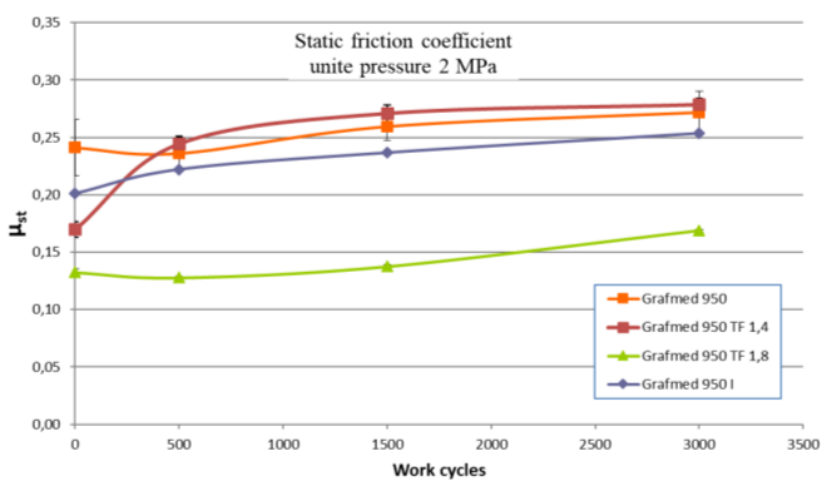

Fig. 8 Static friction coefficient dependence on the number of work cycles for selected material sets for $2 \mathrm{MPa}$ pressure

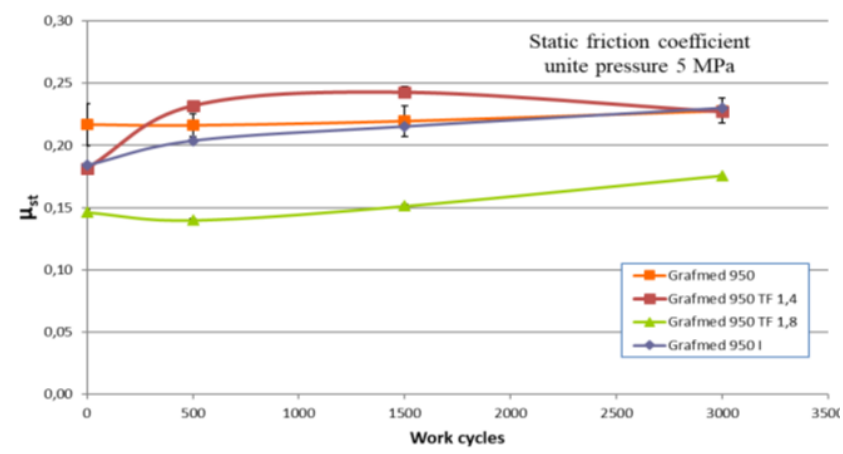

Fig. 9 Static friction coefficient dependence on the number of work cycles for selected material sets for $5 \mathrm{MPa}$ pressure

\subsection{Density}

Two identical Grafmet 950 FT materials, but with different densities of -1.4 and $1.8 \mathrm{~g} / \mathrm{cm}^{3}$, were selected for the tests. The obtained results show the influence of the density of the tested samples on the static friction coefficient (Fig. 10). A decrease in the friction coefficient is visible for the material with higher material density, which is confirmed by the tests performed by [12].

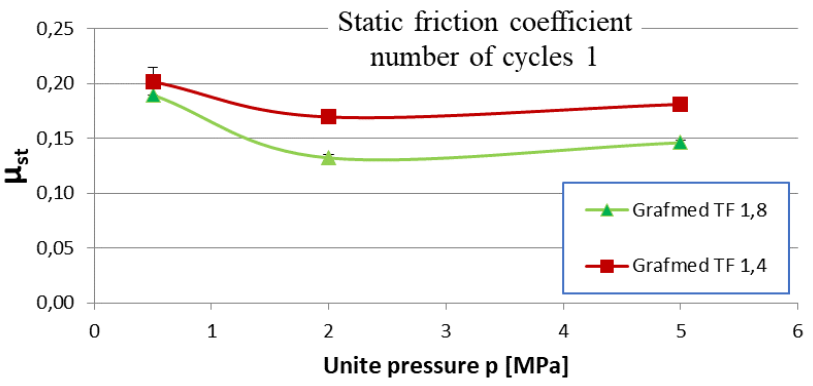

Fig. 10 Static friction coefficient dependence on the pressure for Grafmet TF rings with a density of 1.4 and $1.8 \mathrm{~g} / \mathrm{cm}^{3}$, respectively

\subsection{Mass loss of graphite samples}

Results of mass consumption of material samples for various graphite materials after 3000 cycles are presented in Fig. 11. After each series of tests, i.e. 3000 cycles, the samples were weighed. Then, for each set, the volumetric wear of samples was determined depending on its density. The lowest wear was recorded for Grafmet 950TF 1.8 and the highest for pure graphite - Grafmet 950. 


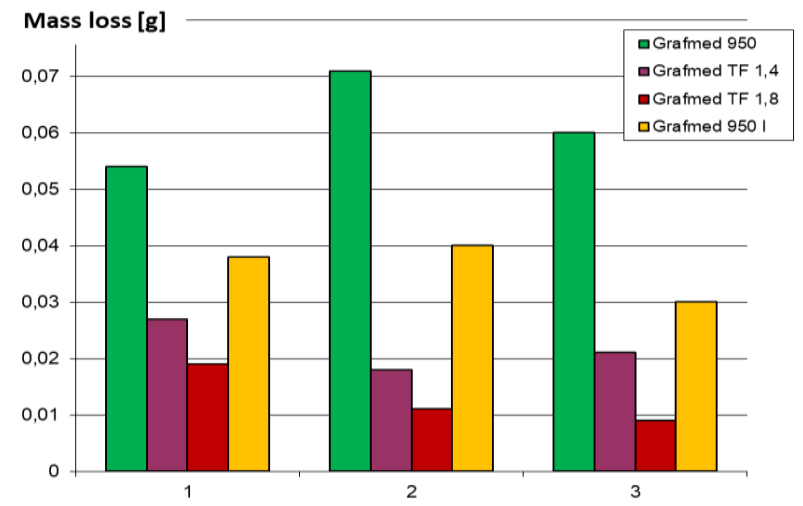

Fig. 11 Changes of samples mass of selected material sets after 3000 cycles for individual series 1, 2, 3

\subsection{Layer}

After the test of the material combination in a given series, the mandrel and rings were subjected to macroscopic examination with the naked eye. The research allowed for a preliminary assessment of the surface structure (Table 3). The following pictures were taken with a

Table 3

Surface macrostructure of steel mandrels and graphite rings after 3000 cycles

\begin{tabular}{|c|c|c|}
\hline $\begin{array}{c}\text { Set of } \\
\text { materials }\end{array}$ & Steel mandrel & Graphite ring \\
\hline $\begin{array}{l}\text { Grafmet } \\
950\end{array}$ & & \\
\hline $\begin{array}{l}\text { Grafmet } \\
950 \mathrm{TF} \\
1,8\end{array}$ & & \\
\hline $\begin{array}{l}\text { Grafmet } \\
950 \mathrm{TF} \\
1,4\end{array}$ & & \\
\hline $\begin{array}{l}\text { Grafmet } \\
950 \text { I }\end{array}$ & & \\
\hline
\end{tabular}

commercial camera in RAW format (a $105 \mathrm{~mm}$ Nikkor lens, exposure time 1/640 seconds, f/11 aperture, ISO 200, tripod).

The appearance of both the mandrel and the rings differed for the tested sets of materials (Table 3). Analyzing the presented photos, it can be noticed that the ring made of pure graphite Grafmet 950 was characterized by the highest wear, the fragments of the ring were torn out. In addition, the layer formed on the surface of the steel mandrel is uneven over the entire surface. The material with the lowest coefficient of friction - Grafmet 950 TF 1.8 - produced a smooth surface on the steel surface.

\section{Summary and conclusions}

The results obtained during tribological research allowed to formulate the following conclusions and observations:

- it was found that the difference in the static friction coefficient was noticeable for the tested sets of materials; the ring made of expanded graphite with PTFE and density of $1.8 \mathrm{~g} / \mathrm{cm}^{3}$ had the lowest static friction coefficient;

- the influence of the load on the static friction coefficient is noticeable; with the increase of the load, the coefficient decreased; with low pressures - $0.5 \mathrm{MPa}$ - a high instability of the friction coefficient value is noticeable (especially for pure graphite);

- with the increase in the number of the combination work cycles, the static friction coefficient increases, especially at $0.5 \mathrm{MPa}$ load;

- the highest mass wear of rings made of pure expanded graphite was observed; at the load of $5 \mathrm{MPa}$, the rings were significantly damaged; for rings made of graphite with PTFE and density of $1.8 \mathrm{~g} / \mathrm{cm}^{3}$ the consumption was the lowest;

- it should also be noted that a layer on the steel surface of the combination, which is characteristic for the interaction between steel and graphite, is also noteworthy; the layer resulting from the interaction of graphite with PTFE with a density of $1,8 \mathrm{~g} / \mathrm{cm}^{3}$ with a steel mandrel is thinner and smoother when compared to the other rings; the literature is not clear on the factors influencing its formation and the tribological processes occurring during its formation, which encourages further research in this direction.

\section{References}

1. Jara A. D.; Betemariamb A.; Woldetinsaec G.; Kimad, J. Y. 2019. Purification, application and current market trend of natural graphite: A review, International Journal of Mining Science and Technology 29: 671-689.

https://doi.org/10.1016/j.ijmst.2019.04.003.

2. Pierson, H. O. 1994. Handbook of Carbon, Graphite, Diamonds and Fullerenes 1st Edition Processing, Properties and Applications ISBN: 9780815517399.

3. Daia, C.; Gua, Ch.; Baoche, L.; Lyua, Y.; Yaoa, X.; Hea, H.; Fanga, J.; Zhao, G. 2019. Preparation of low-temperature expandable graphite as a novel steam plugging agent in heavy oil reservoirs, Journal of Molecular Liquids Volume 293: 111535. https://doi.org/10.1016/j.molliq.2019.111535. 
4. Frąc, M. 2015. Właściwości elektryczne i termoelektryczne wielofunkcyjnych kompozytów cementowych z grafitem ekspandowanym, Doctoral Thesis AGH, Kraków.

5. Zechao, T.; Hongbao, W.; Xiangfen, L.; Zhanju, L.; Quangui, G. 2017. Expanded graphite / polydimethylsiloxane composites with high thermal conductivity, Journal of Applied Polymer Science, 134: Issue 21. https://doi.org/10.1002/app.44843.

6. Bannov, A. G.; Timofeeva, A. A.; Shinkarev, V. V.; Dyukova, K. D.; Ukhina, A. V.; Maksimovskii, E. A.; Yusin, S. I. 2014. Synthesis and studies of the properties of graphite oxide and thermally expanded graphite, Prot. of Met. and Phys. Chem. of Surfaces 50: 183-190.

7. Fadin, V.; Aleutdinova, M.; Belyaev, S.; Tarasov, S. 2005. Wear of Gadfield steel-base sintered composite at current collection sliding, Mechanika 6(56).

8. Rewolińska, A.; Kowalewski, P.; Perz, K.; Paczkowska, M. 2016. A study of friction in reciprocating movement of sliping pair steel-expanded graphite, Tribologia 6: 131-138.

9. Tasdemir, M.; Babat, V.; Yerlesen, U. 2014. Effect of friction and wear parameters on acrylonitrile butadiene styrene/aluminum-boron carbide-glass spheres polymer composites, Mechanika 20(4): 407-413.

10. Nosal, S. 2016. Tribologia, Wprowadzenie do zagadnień tarcia, zużywania i smarowania WPP, Poznań.

11. Norbert, D.; Kusznierewicz, Z.; Rymuza, Z. 2011. Pomiary tarcia spoczynkowego w miniaturowych łożyskach ślizgowych polimer-polimer, Pomiary Automatyka Kontrola 57(7): 760-763.

12. Lee, W. K.; Rhee, T. H.; Kim, H. S.; Jang, H. 2013. Effects of Antimony Trisulfide (Sb2S3) on Sliding Friction of Automotive Brake Friction Materials, Met. Mater. Int. 19(5): 1101-1107. https://doi.org/10.1007/s12540-013-5027-x.

13. Dobrowolska, A. 2012. Wpływ nacisku jednostkowego na współczynnik tarcia statycznego wybranych biomateriałów, Aktualne Problemy Biomechaniki 6: 27-30.

14. Dubrovsky, V. V.; Shapovalov, V. V.; Aderikha, A. N.; Pesetskii, S. S. 2018. Effect of hybrid filling with short glass fibers and expanded graphite on structure, rheological and mechanical properties of poly(ethylene terephthalate), Materialstoday Communications 7: 1523.

https://doi.org/10.1016/j.mtcomm.2018.08.002.

15. Liping, T.; Xiaohua, Z. 2015. Effects of the Difference Between the Static and the Kinetic Friction Coefficients on a Drill String Vibration Linear Approach, Research Article - Mechanical Engineering, Arab J. Sci Eng. 40: 3723-3729. https://doi.org/10.1007/s13369-015-1855-y.

16. Zhanga, G.; Rashevaa, Z.; Schlarbb, A. K. 2010. Friction and wear variations of short carbon fiber
(SCF)/PTFE/graphite (10 vol.\%) filled PEEK: effects of fiber orientation and nominal contact pressure, Wear 268: 893-899.

https://doi.org/10.1016/j.wear.2009.12.001.

17. Zhang, X. R.; Pei, X. Q.; Wang, Q. H. 2009. Friction and wear studies of polyimide composites filled with short carbon fibers and graphite and micro SiO2, Mater. Des. 30: 4414-4420.

https://doi.org/10.1016/j.matdes.2009.04.002.

18. Ścieszka, S. 1998. Hamulce cierne. Zagadnienia materiałowe, konstrukcyjne i tribologiczne, ITE Radom, Gliwice.

19. Nosal, S.; Orłowski, T. 2010. Wpływ rodzaju użytego grafitu i koksu naftowego na właściwości tarciowozużyciowe materiałów ciernych, Tribologia 5: 85-93.

20. Roea, M.; Torranceb, A. A. 2008. The surface failure and wear of graphite seals, Tribology International 41(11): 1002-1008. https://doi.org/10.1016/j.triboint.2008.03.006.

A. Rewolińska, K. Perz, G. Kinal

EXPERIMENTAL TESTS OF STATIC FRICTION COEFFICIENT FOR SELECTED MATERIAL COMBINATIONS OF EXPANDED GRAPHITE - STEEL USED IN SEALING NODES

S u m m a r y

The paper presents the results of static friction coefficient tests of selected material sets used in sealing nodes. Four graphite materials were tested - pure expanded graphite, expanded graphite with the addition of PTFE plastic of different densities $\left(1.4\right.$ and $\left.1.8 \mathrm{~g} / \mathrm{cm}^{3}\right)$ and expanded graphite laminated with austenitic steel foil matching the steel surface. The combinations operated in a reciprocal movement. The measurements were made at different unit pressures $(0.5,2$ and $5 \mathrm{MPa})$ and for different work cycles $(0,500,1500$ and 3000). On the basis of the results obtained, it was found that both the load and the number of work cycles have a significant influence on the value of the static friction coefficient of the tested materials. Not without significance is also the density of selected graphite materials. It was found that expanded graphite with PTFE and density of $1.8 \mathrm{~g} / \mathrm{cm}^{3}$ was characterized by the lowest static friction coefficient in comparison with other materials. It is also worth noting the fact of a layer on the steel surface of combination which promotes the formation of stick-slip phenomenon.

Keywords: expanded graphite, PTFE plastic, static friction coefficient, density, sealing.

Received July 22, 2019

Accepted April 15, 2020 